\title{
Bioclimatic typology of Jujuy Province (Argentina)
}

\author{
Gabriela S. Entrocassi (*), Dante F. Hormigo (**), \\ Rosario G. Gavilán (***) \& Daniel Sánchez-Mata $(* * *)$
}

\begin{abstract}
Entrocassi, G.S., Hormigo, D.F., Gavilán, R.G. \& Sánchez-Mata, D. Bioclimatic Typology of Jujuy province (Argentina). Lazaroa 35: 07-18 (2014).

We report for the first time the Bioclimatic Typology of Jujuy Province (Argentina) as a result of the characterization performed following the methodology of the Bioclimatic Classification of Earth. Temperature and precipitation climatic parameters were used and annual and seasonal bioclimatic indices were also calculated. From them we determined the bioclimatic units and three bioclimatic maps were developed. The results show that the Province of Jujuy falls within the Tropical Macrobioclimate, regardless of the height above sea level at any location; and also present two types of bioclimates: Tropical Xeric and Tropical Pluviseasonal. In the region of the Puna and the Eastern Cordillera (Eastern Andes mountain range), above $2500 \mathrm{~m}$ asl, dominates the Tropical Xeric bioclimate, and the supra-, oro- and criorotropical belts with dry to semiarid ombrotypes, although there are some high and cold places with Tropical subhumid Pluviseasonal bioclimate. The region of the lower valleys and Sierras Subandinas has Tropical Pluviseasonal bioclimate with thermo-, meso- and supratropical thermotypes and humid and subhumid ombrotypes, while the warmer valleys located at the threshold to the Chaco Plain mainly show a dry Tropical Xeric bioclimate. This research properly reflects reciprocity between climate and the distribution of existing vegetation at the province level. On the other hand, it will provide valuable information that may be used in future research and applied projects planning, management and conservation of natural resources of this wide territory.
\end{abstract}

Keywords: Worldwide Bioclimatic Classification, Tropical Pluviseasonal, Tropical Xeric, Puna, Cordillera Oriental, Sub-Andean mountains, Santa Barbara mountains, Jujuy, Argentina.

Resumen: Entrocassi, G.S., Hormigo, D.F., Gavilán, R.G. \& Sánchez-Mata, D. Tipología Bioclimática de la Provincia de Jujuy (Argentina). Lazaroa 35: 07-18 (2014).

Se presenta por primera vez la Tipología Bioclimática de la Provincia de Jujuy (Argentina) como resultado de la caracterización realizada siguiendo la metodología de la Clasificación Bioclimática de la Tierra de Salvador Rivas-Martínez. Para ello se utilizaron parámetros de temperatura y precipitación y se calcularon los índices bioclimáticos de termicidad y ombrotérmicos anuales y estacionales, a partir de los cuales se determinaron las unidades bioclimáticas existentes y se confeccionaron tres mapas bioclimáticos (Bioclimas, Termotipos y Ombrotipos). Los resultados obtenidos demuestran que la Provincia de Jujuy está comprendida en el macrobioclima Tropical, independientemente de la altura sobre el nivel del mar en que se encuentre cualquier localidad; y presenta dos tipos de bioclimas: Tropical Pluviestacional y Tropical Xérico. En la región de la Puna y de la Cordillera Oriental, por encima de $2.500 \mathrm{msnm}$, domina el bioclima Tropical Xérico y se presentan los pisos bioclimáticos supratropical, orotropical y criorotropical con ombrotipos seco a semiárido principalmente, aunque existen ciertos enclaves altos y fríos con bioclima Tropical Pluviestacional subhúmedo. La región de los valles bajos y Sierras Subandinas goza de bioclima Tropical Pluviestacional con termotipos termotropical, mesotropical y supratropical y ombrotipos subhúmedo y húmedo, mientras que los valles más cálidos ubicados en el umbral con la Llanura Chaqueña presentan nuevamente bioclima Tropical Xérico seco principalmente. La Tipología Bioclimática de la Provincia de Jujuy que se da a conocer en este trabajo, sienta el primer precedente de utilización y puesta a prueba de la Clasificación Bioclimática de la Tierra a escala provincial, y aunque es susceptible de futuros ajustes, refleja adecuadamente la reciprocidad entre el clima y la distribución de las formaciones vegetales existentes. Por otro lado, brindará valiosa información que podrá ser utilizada en futuras investigaciones y aplicada en proyectos de ordenamiento, manejo y conservación de los recursos naturales del territorio provincial.

Palabras clave: Clasificación Bioclimática de la Tierra, Tropical Pluviestacional, Tropical Xérico, Puna, Cordillera Oriental, Sierras Subandinas, Sistema de Santa Bárbara, Jujuy, Argentina.

\footnotetext{
* Cátedra de Botánica Sistemática y Fitogeografía. Laboratorio de Botánica Sistemática y Etnobotánica - Área de Biogeografía Aplicada. Facultad de Ciencias Agrarias. Universidad Nacional de Jujuy. gsentrocassi@yahoo.com.ar

** Cátedra de Topografía. Departamento de Suelo, Clima y Ecología. Facultad de Ciencias Agrarias. Universidad Nacional de Jujuy.dfhormigo@hotmail.com

*** Departamento de Biología Vegetal II. Facultad de Farmacia. Universidad Complutense de Madrid. E-28040 Madrid. Spain. Email: rgavilan@ucm.es; dsmata@ucm.es.
} 


\section{INTRODUCTION}

Jujuy province is located in the far north of the Republic of Argentina, between $21^{\circ} 46^{\prime}-24^{\circ} 36^{\prime}$ $\mathrm{S}$ and $64^{\circ} 10^{\prime}-67^{\circ} 11^{\prime} \mathrm{O}$ (Figure 1). It is intersected by the Tropic of Capricorn, and presents a highly diverse and heterogeneous territory, containing several ecological belts and ecosystems as a result of its steep altitudinal gradient (between 300 and $6,200 \mathrm{~m}$ asl), and extending across four major geological units that cross the territory from north to south: the puna -a raised plain standing at an altitude of over 3,700 m asl-, the Cordillera Oriental range, the sub-Andean mountain ranges, and the Santa Bárbara mountains (RAMOS, 1999). It includes Punean and high-Andean plateaus and mountain chains, pre-Punean inter-Andean valleys, sub-Andean mountains exposed to moist air masses, and foothills and low-lying warm valleys located on the threshold of the Chaco plain. This situation leads to a very rich environmental and biological diversity, as seen from the fact that Jujuy province is located in the Argentinian region with the highest diversity of vascular plants at the family, genus and species level, as well as containing the greatest number of endemic species (ZULOAGA \& al., 1999) as in close South American areas (LUEBERT \& GAJARDO, 2001).

There are relatively few climate studies on Jujuy province. BuITRAGO (2000) laid the foundations of climate information on the province using the Köppen classification (1936) to describe the climate types present in the area; however this classification does not allow the quantitative expression of the relationship between climate and the distribution of organisms -basically vegetation-which, due to its

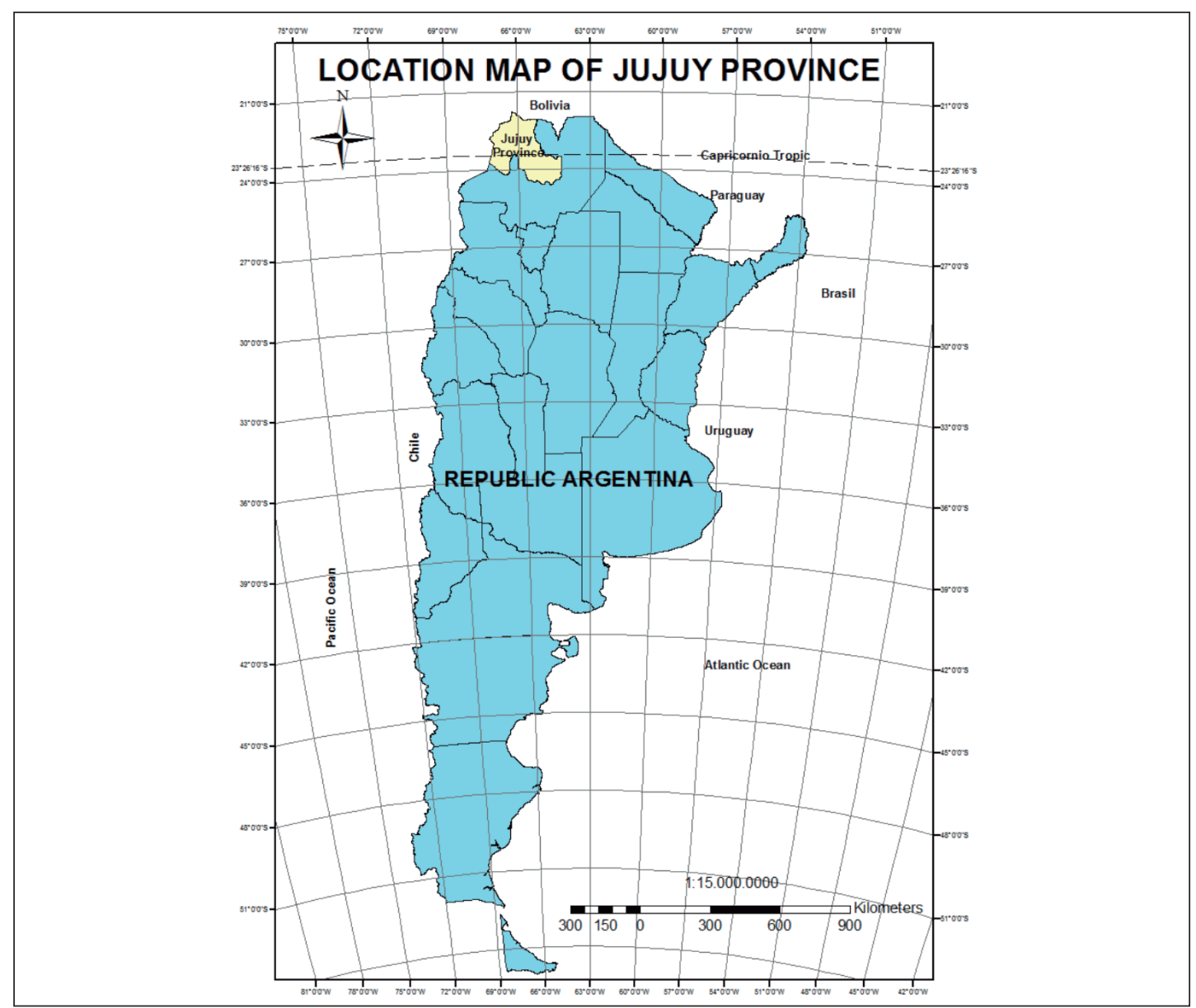

Figure 1. - Location of the study area (Jujuy Province, Argentina). 
static nature, is the most obvious component of ecosystems. In 1994 RivAS-MARTíNEZ \& NAVARRO proposed a Bioclimatic Essay for South America based on the Worldwide Bioclimatic Classification System (RIVAS-MARTíneZ, 1991). This essay is a modern bioclimatic study at the continental scale using a range of bioclimatic indices. The classifications made with these types of indices not only make it possible to determine different climate types and their areas of geographic distribution, but also allow a quantitative analysis of the relationship between climate and the distribution of living beings; that is to say, the reciprocal relationship between specific climate values and the distribution of organisms, particularly vegetation. The aforementioned essay provided the bioclimatic typification of the Jujuy province within the context of South America, and this became the basis for embarking on a further study at a greater scale within the province, as presented in this work.

Of all the bioclimatic classifications in use today, the Worldwide Bioclimatic Classification System by RIVAS-MARTínEZ (2008) and Rivas-MarTínEZ \& al. (1999) has proved to be the most comprehensive, as it constitutes an eclectic highly predictive and reliable bioclimatic model that can be applied to any point on the planet. In the present study we therefore chose to work with this model of bioclimatic classification in order to establish a detailed bioclimatic typology of Jujuy province that accurately reflects the climate types and their distribution in the territory, in addition to the correspondence between these types and the distribution of the main vegetation units.

\section{MATERIALS AND METHODS}

The bioclimatic typology of Jujuy province was determined according to the Worldwide Bioclimatic Classification System of Rivas-MARTíNEZ (2008) and RiVAS-MARTÍNEZ \& al. (1999).

This work studied 121 localities in Jujuy province using simple climate parameters and the bioclimatic indices that express the interrelations between these parameters, calculated according to simple arithmetic formulae.

The climate parameters with the greatest diagnostic value used in this characterisation are the following: Mean annual temperature (T), Mean monthly temperature (Ti), Mean maximum temperature of the coldest month (M), Mean minimum temperature of the coldest month (m), Annual positive temperature (Tp), Positive temperature of the driest six months of the year (Tpd2); Mean annual precipitation (P), Mean monthly precipitation $(\mathrm{Pi})$, Positive yearly precipitation (Pp), Positive precipitation of the driest six months of the year ( $\mathrm{Ppd} 2)$, Precipitation in the warmest month of the year (Pss) and Precipitation in the coldest six months of the year (Psw).

The climate data for temperature and rainfall were obtained from the available climate statistics from the National Meteorological Service (ANON., 1921-1950; ANON., 1951/60, 1961/70, 1971/80, 1981/90) and other relevant bibliography (BIANCHI, 1981; BiANCHI \& YÁÑEZ, 1992; BiANCHI, 1996; BIANCHI \& al., 2005). When there were no records for a locality on the climate parameters studied, their values were calculated by extrapolating the data from two nearby localities. This is the case of parameters such as mean maximum temperature of the coldest month (M) and mean minimum temperature of the coldest month (m), which were estimated by first calculating the altitudinal thermal gradient, and then adding or subtracting this value from the known values for $\mathrm{M}$ and $\mathrm{m}$ for one of the localities considered in the extrapolation.

Temperature and precipitation data were used to calculate the following Rivas-Martínez bioclimatic indices: Thermicity index (It), Annual ombrothermic index (Io), and Ombrothermic index of the driest two months of the year $(\operatorname{Iod} 2)$.

Using specific keys, and based on the values of these parameters and bioclimatic indices, we determined the macrobioclimate and the bioclimates for the whole of the Jujuy province. We also determined the different bioclimatic belts (thermotypes and ombrotypes) presents in each bioclimate, and their respective bioclimatic horizons (upper and lower).

The following parameters were considered for the determination of the macrobioclimate: Mean annual temperature (T), Mean maximum temperature of the coldest month (M), Thermicity index (It), Precipitation in the warmest six months of the year (Pss) and Precipitation in the coldest six 
months of the year (Psw). Since all the localities studied are located above $200 \mathrm{~m}$ asl, in order to determine the macrobioclimate we had to theoretically calculate the temperature values at that height, and increase $\mathrm{T}$ by $0.6^{\circ} \mathrm{C}, \mathrm{M}$ by $0.5^{\circ} \mathrm{C}$ and It by 13 units for every 100 metres above that altitude, as established in the Worldwide Bioclimatic Classification.

To determine the predominant bioclimate in each locality, we considered the values of the annual ombrothermic index (Io) and the ombrothermic index of the driest six months of the year (Iod2).

To determine the thermotypes and ombrotypes and their horizons (upper and lower) we considered the values of the thermicity index (It) and the annual ombrothermic index (Io); when necessary -as a consequence of the influence of altitudewe used the positive annual temperature (Tp).
Finally, we compiled three bioclimatic maps showing, respectively, the bioclimates (Map 1), the thermotypes (Map 2) and the ombrotypes (Map 3) for Jujuy province, and using the bioclimatic indices calculated for the 121 localities, and the altitudinal and latitudinal ranges in each bioclimate established. As basic information we also considered digital cartography (populations, contour lines, political division) from the Geographic Information System at a scale of 1:250,000 (SIG 250) from the National Geographic Institute (IGN) of the Republic of Argentina (ANON., 2007).

By processing this information with a Geographic Information System, we generated vectorial layers to define the limits of each bioclimatic unit and its geographic distribution throughout the province, with which we subsequently compiled the bioclimatic maps of Jujuy province.

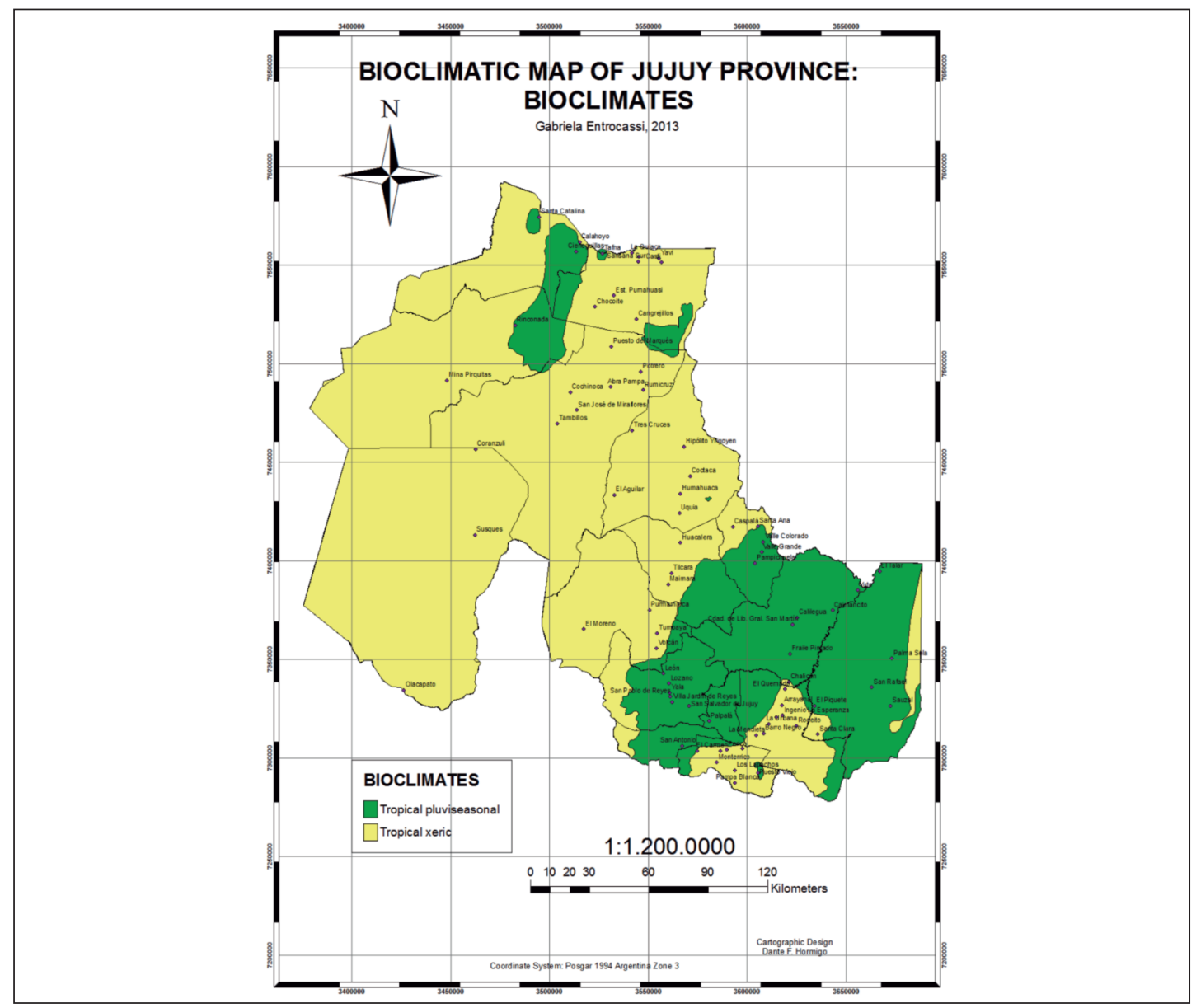

Mapa 1. - Bioclimatic map of Jujuy Province; bioclimate types: Tropical Pluviseasonal and Tropical Xeric. 


\section{RESULTS AND DISCUSSION}

The results obtained are consistent with the theoretical body and the methodology of the Worldwide Bioclimatic Classification and allow us to assert the following:

1- Jujuy province lies within the Tropical Macrobioclimate, regardless of the altitude of any of the localities in the province. The bioclimate is Tropical in nature, as it satisfies the following conditions, namely:

The province is located in the EutropicalSubtropical latitudinal belt (between $21^{\circ} 46^{\prime}$ and $24^{\circ} 36^{\prime} \mathrm{S}$ ) and is intersected by the Tropic of Capricorn, thus receiving large amounts of solar radiation. Average annual overall radiation in the
Puna and high-Andean region is $466 \mathrm{cal} / \mathrm{cm}^{2}$ day, whereas in the lower-lying and warmer subAndean valleys it is $383 \mathrm{cal} / \mathrm{cm}^{2}$ day. Furthermore, as a result of its latitudinal position and its exposure to radiation, there are no major variations in the length of the day throughout the year. For example, in the locality of La Quiaca located in the far north of the province, on the border with the Republic of Bolivia, the duration of the day on the summer solstice is $13: 30 \mathrm{~h}$ and $10: 43 \mathrm{~h}$ on the winter solstice, while in the far south, in the locality of Pampa Blanca, the duration is $13: 40 \mathrm{~h}$ and $10: 35 \mathrm{~h}$ on the same dates (Buitrago, 2000).

The high amounts of solar radiation this region receives determines the existence of continuous vegetative activity throughout the whole year.

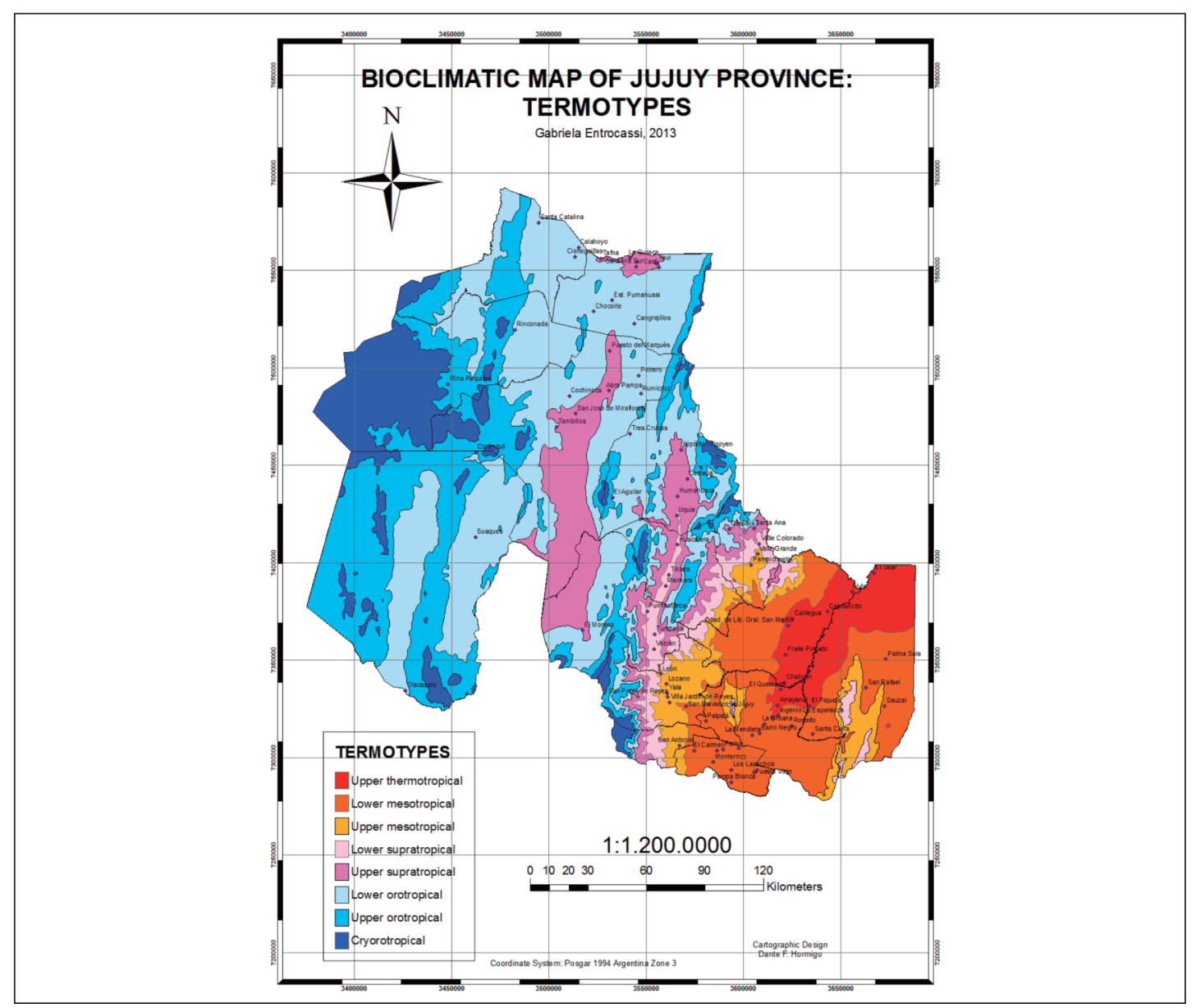

Mapa 2. - Bioclimatic map of Jujuy Province; thermotypes: upper thermotropical, lower mesotropical, upper mesotropical, lower supratropical, upper supratropical, lower orotropical and upper orotropical and cryorotropical. 
Even in the Andean high mountains and high plains, where the daily temperature rhythm alternates between severe night frosts and high temperatures during the day, vegetative activity can be considered to be maintained practically without interruption all year round (RIVAS-MARTíNEZ, 2000).

According to the bioclimatic classification used in this work, the province satisfies the requisite values for Mean annual temperature $(\mathrm{T})$, Mean maximum temperature in the coldest month $(M)$ and for the Thermicity index (It).

The period of maximum precipitation takes place at the time of the greatest amount of solar radiation, and hence in the warmest part of the year. $80 \%$ of the precipitation in the province falls between November and March.
2- Jujuy province has two types of bioclimate: Tropical Pluviseasonal and Tropical Xeric (Map 1).

The Tropical Pluviseasonal bioclimate occurs in an environment of great topographic complexity and marked altitudinal gradient, between 300 and $4150 \mathrm{~m}$ asl (according to the localities studied, although it could reach higher altitudes in some sites in the mountain range, for which unfortunately there are no reliable climate records).

This bioclimate occupies a broad swathe in the south of Jujuy province, and covers a region exposed to warm air masses from the Atlantic Ocean, comprising the sub-Andean mountain ranges, the Santa Bárbara mountains, and the San Francisco river valley, following an altitudinal gradient of 320 to $2120 \mathrm{~m}$ asl approximately. In the mountains the precipitations are primarily of an orographic

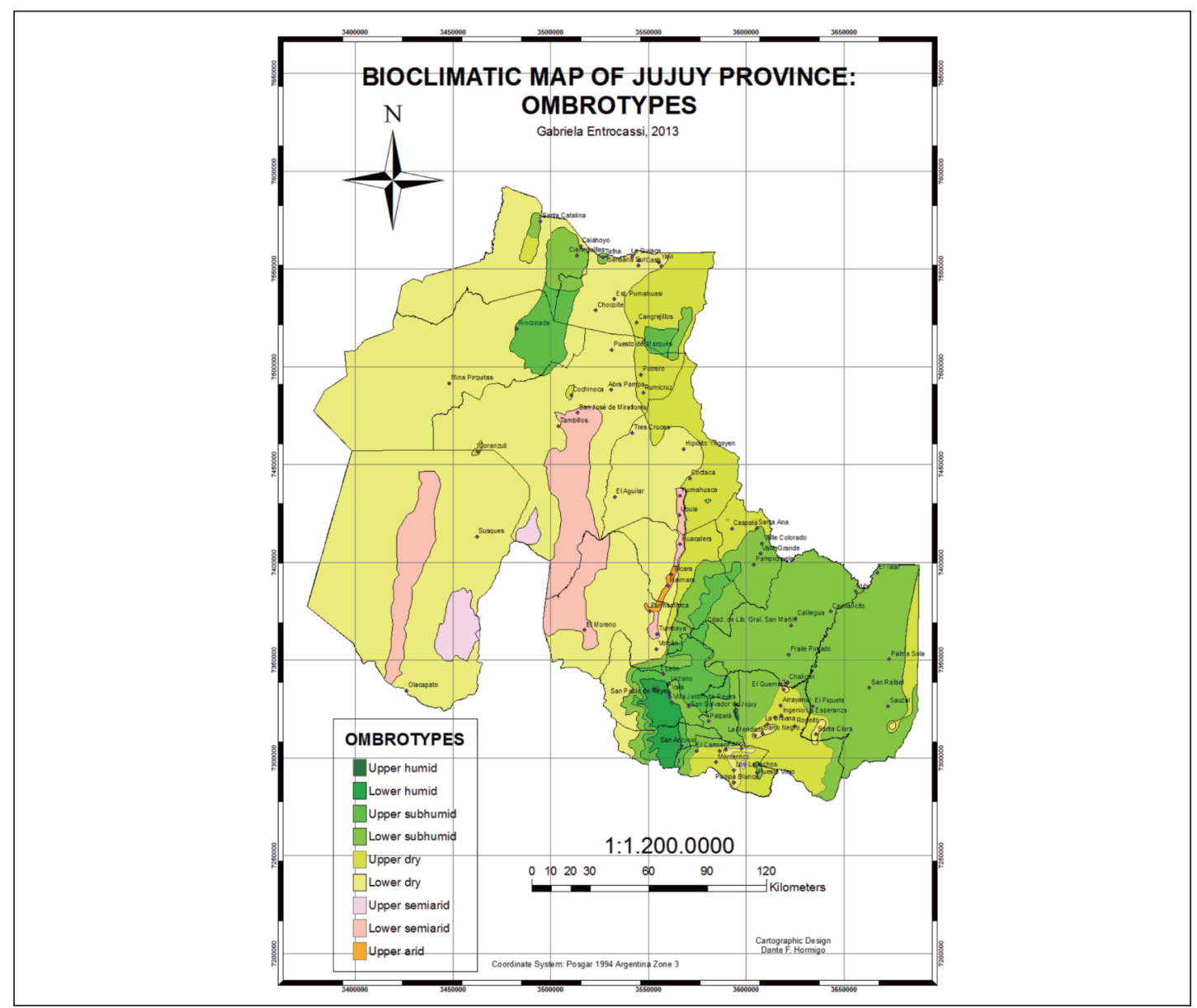

Mapa 3. - Bioclimatic map of Jujuy Province; ombrotypes: upper subhumid, lower subhumid, upper humid, lower humid, lower dry, upper dry, upper semi-arid, lower semi-arid and upper arid. 
nature, as the moist winds are forced up the mountainsides, cooling adiabatically as they rise until they reach condensation temperature. In the lowlying valleys where the highest temperatures are recorded, there is greater predominance of convection-type precipitations caused by the warming of the Earth's surface (BUITRAGO, 2000).

The Tropical Pluviseasonal bioclimate is also found in some high, cold and subhumid localities in the puna and the Cordillera Oriental range between 2450 and $4150 \mathrm{~m}$ asl. These enclaves are Pluviseasonal due to the fact that both their location and their topographic characteristics mean they are exposed to the influence of the remaining moist air masses that flow into the province from the eastern quadrant, crossing the Santa Victoria and Zenta mountain ranges, and discharging both orographic- and convection-type precipitations along their way.

From the biogeographic standpoint, this bioclimate extends throughout the humid and subhumid areas of the Boliviano-Tucuman province, a biogeographical territory belonging to the great Andean Region (Rivas-Martínez \& NaVARro, 1994; NAVARro \& MALDONADO, 2004), and which -due to its altitude-determines the existence of different ecological belts and ecosystems and the development of various plant formations such as Pluviseasonal semi-deciduous seasonal evergreen forests, montane cloud grasslands and shrubby and herbaceous subhumid steppes. According to CABRERA (1994) and CABRERA \& WILLINK (1973) this bioclimate covers mainly the phytogeographical province of Las Yungas, and contains a classic formation of Tucumano-Bolivian rainforest (HAUMAN, 1931); it appears in small subhumid enclaves corresponding to the Chacoan (Distrito Chaqueño Serrano), pre-Punean and Punean phytogeographical provinces.

The Tropical Pluviseasonal bioclimate is represented in 68 of the localities studied, and extends partially or totally across the departments of Dr. Manuel Belgrano, Palpalá, El Carmen, San Antonio, San Pedro, Ledesma, Santa Bárbara and Valle Grande, appearing in some high-mountain Pluviseasonal regions in the departments of Tilcara, Tumbaya, Humahuaca, Rinconada, Santa Catalina and Yavi.
The thermotypes that occur in this bioclimate are, from the warmest to the coldest: upper thermotropical, lower mesotropical, upper mesotropical, lower supratropical, upper supratropical, lower orotropical and upper orotropical (Table 1 and Map 2).

The thermotropical belt occupies the lower and warmer areas corresponding to the San Francisco river basin (between 320-500 m asl). On ascending up the sub-Andean mountain ranges and the Santa Bárbara mountains the temperature decreases, leading to the appearance of the lower and upper mesotropical and lower supratropical belts up to an approximate altitude of $2450 \mathrm{~m}$ asl. These thermal belts determine the development of extensive dense wooded Pluviseasonal areas with high diversity, characterised by semi-deciduous and seasonal evergreen micro- and mesoforests, and by montane cloud grasslands and herblands.

In the high and subhumid regions of the puna and the Cordillera Oriental range, from $2500 \mathrm{~m}$ asl, the drop in temperature leads to the appearance of colder thermal belts, from the upper supratropical to the upper orotropical, causing the development of open plant formations such as low copses and subhumid shrubby and herbaceous steppes typical of the Cordillera and puna regions.

The ombrotypes in this bioclimate are, in increasing order of humidity: lower subhumid, upper subhumid, lower humid and upper humid (Table 1 and Map 3).

The subhumid ombrotype -mainly the lower subhumid-covers a broad territory and is found at different altitudes; whereas the humid ombrotype is circumscribed by a sector in the southwest of the province, forming a continuous area between 1150 and $2060 \mathrm{~m}$ asl, and is also found in a few enclaves located between 1950 and $2120 \mathrm{~m}$ asl.

The Tropical Xeric bioclimate covers the greatest area in Jujuy province, including the puna and Cordillera Oriental region extending leeward of the moist air masses between 2000 and 4100 $\mathrm{m}$ asl approximately, occupying high valleys, high plains, high mountains and the Quebrada de Humahuaca mountain valley. The winds that arrive in this region are practically dry, as the air masses have discharged their humidity on the eas- 


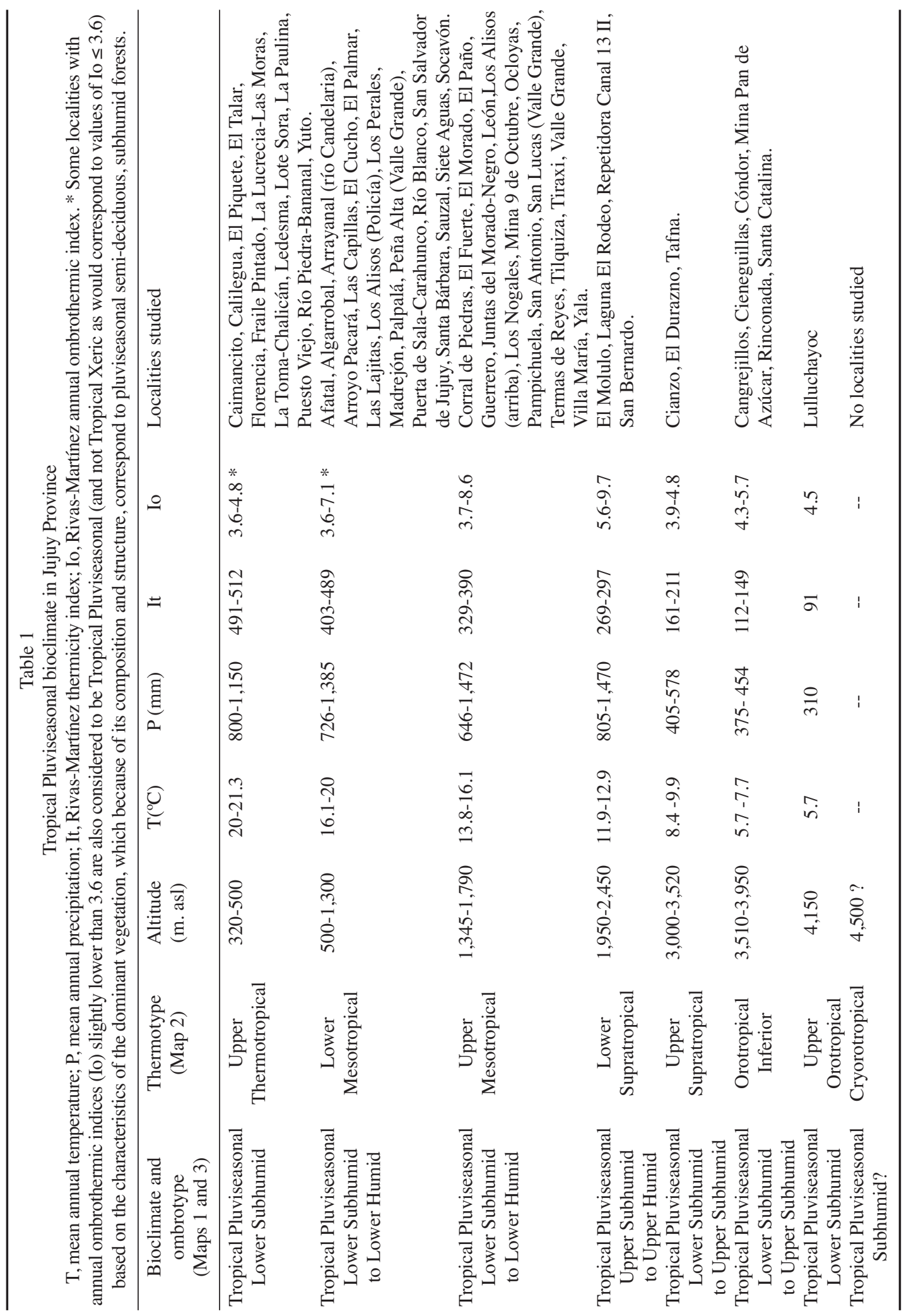


tern slopes of the mountain chains located in the eastern quadrant of the province.

The Tropical Xeric bioclimate is also found to a lesser degree- in the warm region in the far south-southeast of the province, occupying dry low-lying valleys and mountain ranges between 400 and $1100 \mathrm{~m}$ asl approximately. This region is the warmest in the province and falls under the physiographic influence of the Gran Chaco; for this reason the air masses are dry or carry very little moisture, as this has already been discharged over the lower slopes or over the broad Chaco plain in the form of convection precipitations (Buitrago, 2000).

From the biogeographical standpoint, this bioclimate extends across the dry and semi-arid areas of the Boliviano-Tucuman and Altiplano provinces in the Andean biogeographic region (RIVAS-MARTÍNEZ \& NAVARRO, 1994; NAVARRO \& MALDONADO, 2004), giving rise to the development of a variety of plant formations according to their altitude. Thus in the high cold regions of the puna and the Cordillera Oriental range, the typical plant formations are herbaceous and shrubby steppes, cactus groves and open xerophytic microforests; whereas in the warm low-lying valleys of the far south-southeast of the province this bioclimate enables the establishment of dense xerophytic microforests and shrublands with a Chacoan character. According to CABRERA (1994) and CABRERA \& WILLINK (1973) this covers mainly the pre-Punean and Punean phytogeographical provinces towards the north and the Chacoan province (Distrito Chaqueño Serrano) in the far south-southeast.

This bioclimate is represented in 53 of the localities studied and extends, partially or totally, across the departments of Tumbaya, Tilcara, Valle Grande, Humahuaca, Cochinoca, Yavi, Santa Catalina, Rinconada and Susques; in the south-southeast of the province it occupies a substantial area in the departments of El Carmen and San Pedro and a lesser area in the departments of Santa Bárbara, Dr. Manuel Belgrano and San Antonio.

The thermotypes observed in this bioclimate are, from the warmest to the coldest: upper thermotropical, lower mesotropical, lower supratropical, upper supratropical, lower orotropical and upper orotropical (Table 2 and Map 2).
The upper thermotropical and lower mesotropical belts are found only in the far south-southeast of the province; the first occupies the lower-lying areas corresponding to the upper San Francisco river basin and the threshold of the Chaco plain; and the second can be seen ascending gradually up the sub-Andean mountain ranges and the Santa Bárbara mountains to approximately $1100 \mathrm{~m}$ asl.

The lower and higher supratropical and lower and higher orotropical thermal belts are found only in the high, cold, dry regions of the puna and the Cordillera Oriental between 2000 and $4100 \mathrm{~m}$ asl approximately.

The ombrotypes in the Tropical Xeric bioclimate are, in increasing order of humidity: upper arid, lower semi-arid, upper semi-arid, lower dry and upper dry (Table 2 and Map 3). In the region of the puna and the Cordillera Oriental the predominant ombrotype is dry -mainly lower dry-, whereas the upper dry ombrotype is circumscribed to a more humid strip that basically runs north to south following the mountain ranges of Santa Victoria and Zenta in the eastern quadrant of the province. This region corresponds to what is known as the dry puna and is characterised by the existence of permanent lakes and exorheic basins with low precipitation (200 to $350 \mathrm{~mm} /$ year). The areas with a semi-arid ombrotype are distributed in the centre and southwest of the province and correspond to what is known as the desert puna, characterised by lower precipitation (50 to $200 \mathrm{~mm} /$ year) and by the existence of endorheic basins and large salt marshes (Salinas Grandes, Salar de Olaroz and Salar de Cauchari).

In the warm valleys in the far south-southeast of the province, the upper dry ombrotype is predominant, and there are some drier enclaves (lower dry and upper semi-arid).

A particular bioclimatic situation occurs in the region of the Quebrada de Humahuaca valley, whose orientation is not conducive to the inflow of moist air masses. For this reason precipitations undergo a marked decrease from the locality of Tumbaya to Humahuaca in the supratropical bioclimatic belt (between 2000 and $3000 \mathrm{~m}$ asl approximately), leading to the establishment of a semi-arid strip, as indicated by the low values for the ombrothermic 


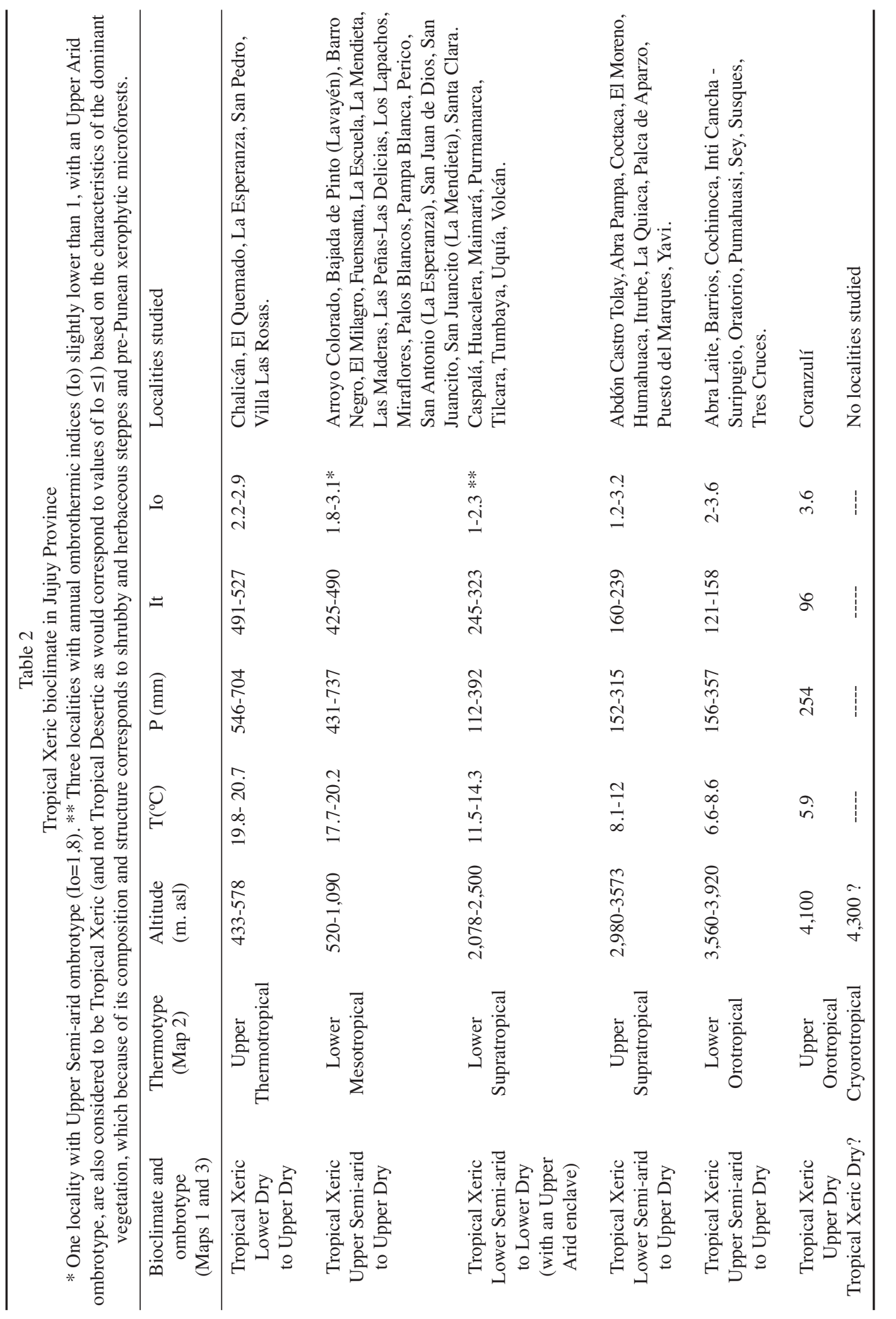


indices $(1 \leq \mathrm{I} 0 \leq 1.5)$. Within this semi-arid strip there are three localities with an upper-arid ombrotype. At between 2000 and $2500 \mathrm{~m}$ asl, these localities should in theory have a tropical desertic bioclimate, and yet the bioclimate is here considered to be Tropical Xeric, as the vegetation composition and structure in these localities is clearly pre-Punean and is characterised by the presence of open microforests, steppes and cactus groves. There are no floristic elements corresponding to a tropical desertic bioclimate (Table 2 and Map 3).

It should be noted that as there are no reliable climate data for some of the localities at altitudes above 4100 metres, we did not include them in the present study; for this reason the altitudes established for the start of the coldest bioclimatic belt the cryorotropical- have a provisional character until such time as reliable climate statistics become available. In view of this, the cryorotropical belt can be estimated to begin at $4500 \mathrm{~m}$ asl in the Tropical Pluviseasonal bioclimate, and at $4300 \mathrm{~m}$ asl in the Tropical Xeric (Tables 1 and 2). These altitudes were estimated taking into account the height of the locality in the previous thermal belt (Upper Orotropical). These values are close to those established for the same thermal belt in Bolivia by NAVARRO \& MALDONADO (2004).

\section{CONCLUSIONS}

In ombroclimatic terms, the most extreme situations in the lower supratropical belt of the Tropical Pluviseasonal and Tropical Xeric bioclimate are manifested between approximately 2000 and $2500 \mathrm{~m}$ asl, as this altitudinal range contains both the most humid areas and the driest areas in Jujuy province.

The most humid areas are found between 1950 and $2450 \mathrm{~m}$ asl within the Tropical Pluviseasonal bioclimate; this altitudinal range is where the effect of orographic precipitation is intensified, a situation that is borne out by the high values of the ombrothermic indices (Table 1) and by the type of vegetation, characterised by large expanses of rainforest and cloud mountain grassland. The driest areas are found between 2078 and $2461 \mathrm{~m}$ asl within the Tropical Xeric bioclimate, and are located in the region of Quebrada de Humahuaca.
This fact can be explained by the movement of the air masses and the effect of the rain shadow. The Lower Supratropical bioclimatic belt stretches like a strip in a northeast-southwest direction in the contact zone between the sub-Andean and Cordillera Oriental mountain ranges. The most humid areas are found in these mountain valleys, windward of the moisture-bearing winds; and the driest areas are in ravines and inter-Andean valleys in the Cordillera Oriental, leeward of these winds. As described earlier, the warm air masses that flow into Jujuy province from the eastern quadrant are forced up the windward slopes of the sub-Andean mountain ranges, and as they rise the water vapour condenses and precipitates in the form of abundant rains which attain their maximum values at an altitude of between 1950 and $2500 \mathrm{~m}$ asl. From this point on, these air masses continue to rise until the mountain barrier, then cross the summits of the Cordillera Oriental carrying very little moisture, and subsequently become drier and cooler due to orographic subsidence through the leeward slopes before penetrating into the Quebrada de Humahuaca, making this one of the driest regions in the province. Above and below this critical altitudinal interval (2000-2500 m asl) each bioclimate has particular characteristics as a result of the variations in the predominant climate factors and elements, as described below.

In the territories below $1950 \mathrm{~m}$ asl with a Tropical Pluviseasonal bioclimate the temperatures rise sharply and precipitation decreases gradually, a situation that favours the establishment of warmer and less humid bioclimatic belts. Above 2500 $\mathrm{m}$ asl, in the supratropical and orotropical localities of the puna and Cordillera Oriental (between 3000 and $4100 \mathrm{~m}$ asl) which are more favourably oriented for the inflow of winds with a degree of moisture, there is a combined decrease in temperature and precipitation, and the establishment of colder and less humid bioclimatic belts which -in spite of being less humid-allow the Tropical Pluviseasonal bioclimate to prosper at these altitudes (Table 1).

The territories with the Tropical Xeric bioclimate show two different bioclimatic patterns according to their altitude. In the low, warm dry valleys in the south-southeast of the province located below $1950 \mathrm{~m}$ asl, temperature and preci- 
pitation increase in tandem, a situation which allows the establishment of warmer and less dry bioclimatic belts (Table 2). In the puna and Cordillera Oriental region above $2500 \mathrm{~m}$ asl (between 2500 and $4100 \mathrm{~m}$ asl) the temperature falls and precipitation increases slightly, favouring the presence of colder and less dry bioclimatic belts which, although they are slightly more humid, only allow the Tropical Xeric bioclimate to prosper (Table 2).

These results have allowed us to compile a bioclimatic typology of the province which -although it is of a preliminary nature and is susceptible to future adjustment- establishes the first precedent for use and validation of the Worldwide Bioclima- tic Classification at the provincial scale, as the findings highlight the correspondence between the bioclimatic units that are determined and mapped with the distribution of the main vegetation units in Jujuy province. This typology and the resulting maps provide valuable information that can be used in further research, for example in the fields of biogeography, ecology and agriculture, or in actions associated with the territorial ordination, conservation and sustainable management of natural resources and biodiversity in this territory.

For a clearer interpretation of the maps, we also include Tables 1 and 2, which summarise the bioclimatic characteristics and typology at the provincial level.

\section{REFERENCES}

Anonymous -1921-1950 - Datos Pluviométricos Fuerza Aérea Argentina. Serv. Met. Nal. Publ. B1., Buenos Aires. 147 p.

Anonymous -1951/60, 1961/70, 1971/80, 1981/90 - Estadísticas Climatológicas - Serv. Met. Nal., Buenos Aires.

Anonymous -2007 - Sistema de Información Geográfica Escala 1:250.000 (SIG 250) - Inst. Geogr. Nal. Rep. Argentina

Bianchi, A.R. - 1981 - Las Precipitaciones del NOA Argentino - INTA, Salta.

Bianchi, A.R. - 1996- Temperaturas medias estimadas para la región Noroeste de Argentina - INTA, Est. Exp. Agropecuaria, Salta. 14 pp.

Bianchi, A.R. \& Yáñez. C.E. -1992- Las Precipitaciones en el Noroeste Argentino, 2da Ed. - INTA, Est. Exp. Agropecuaria, Salta.383 p.

Bianchi, A.R., Yáñez, C.E., Acuña, L.R., Elena, H.J. \& Tolaba Martinez, F.G. - 2005- Base de datos mensuales de precipitaciones en el noroeste argentino. Periodo 1934-1990 - http://www.inta.gob.ar.

Buitrago, L.G. - 2000 - El clima de la Provincia de Jujuy 2da ed. - Ed. Univ. Nal. Jujuy. 64 pp.

Cabrera, A.L. \& Willink, A. -1973- Biogeografía de América Latina - Org. Est. Am. (OEA), Washington D.C. vi +117 pp.

Cabrera, A.L. - 1994- Regiones fitogeográficas argentinas - Enciclopedia Argentina de Agricultura y Jardinería. Primera reimpresión. Tomo II, Fasc. 1. Ed. ACME. Buenos Aires. 85 pp.
Chuvieco, E. -1996- Fundamentos de Teledetección, $3^{\circ}$ ed. - Ed. Rialp, Madrid.

Hauman, L. - 1931 - Esquisse phytogéographique de 1' Argentine subtropicale et de ses relations avec la géobotanique sudaméricaine - Bull. Soc. Roy Bot. Belgique 64: 20-80.

Köppen, W. -1936- Grundiss der Klimakunde 2 Aufl. Berlin \& Leipzig. 388 pp. +9 tables.

Luebert, F. \& Gajardo, R. - 2001- Vegetación de los Andes áridos del norte de Chile. - Lazaroa 21: 111-130.

Navarro, G. \& Maldonado, M. - 2004- Geografía Ecológica de Bolivia: Vegetación y Ambientes Acuáticos, 2da ed. - Centro de Ecología Simón I. Patiño. Dep. Dif., Cochabamba. 719 pp.

Ramos, V.A. - 1999- Las Provincias Geológicas del territorio argentine - An. Geol. Argentina 29(3): 41-96.

Rivas-Martínez, S. - 1991 - Clasificación Bioclimática de la Tierra - Folia Bot. Matritensis, 14.

Rivas-Martínez, S. -2008 - Global Bioclimatics (Clasificación Bioclimática de la Tierra) - (http://www.globalbioclimatics.org).

Rivas-Martínez, S. \& Navarro, G. - 1994- Ensayo Bioclimático y Biogeográfico de América del Sur - Comm. VI Congr. Lat. Bot. Mar del Plata. Argentina. Unpubl.

Rivas-Martínez, S., Sanchez-Mata, D. \& Costa, M. 1999 - North American Boreal and Western Temperate Forest Vegetation - Itinera Geobot. 12: 5-316.

Zuloaga, F.O., Morrone, O. \& Rodriguez, D. -1999Análisis de la biodiversidad en plantas vasculares de la Argentina - Kurtziana 27 (1): 17-167. 